\title{
Images of the female countenance in Renaissance literature
}

\author{
Mohammad Reza Modarres Zadeh \\ Faculty of Foreign Languages, The University of Isfahan, Hezar Jerib Boulevard, \\ Darvaze Shiraz Sq. Isfahan, Iran \\ Language Center telephone no: 0098-311-7932122-3 \\ E-mail address:m.modareszadeh@yahoo.com
}

\begin{abstract}
In her article "The politics of gender" Elaine Hobby gives a clear image of the confusion evoked in modern mentality by the juxtaposition of Renaissance literature and history. The romantic scenes portrayed in the wonderland of Renaissance poetry seem uncompromisable with the bare facts of historical record. As we contemplate the shadows obscuring the male permeated poetic language of the age however, we do discern spots of light illuminating the overall picture. The age has its own logic and its own language and although neither may be wholly appealing to the modern palate, both are, within their own historical framework, unequivocal and self-consciously assertive.
\end{abstract}

Keywords: Male/female binary; Renaissance history; Renaissance literature

\section{INTRODUCE}

If we step into the Renaissance literary world and encounter examples of the vast number of poems that portray visages of ideal romance, our sighs may accompany the pitiful Renaissance lover for want of a romantic past so very remote from our own contemporary world. Not few are the poems in which the adoring lover expends sighs and tears and urges his would-be beloved to remember the ultimate infidelity of time and pleads with her in the declaration that:

Thou art my life, my love, my heart

The very eyes of me:

And hast , command of every part

To live and die for thee

(Herrick, ‘To Anthea, who may Command Him Anything' qtd. Hobby 1993, 31). 
Or boasts of his fortune which dwarfs that of regal courts for he and his beloved have the state envied by all princes:

She is all states, and all princes I,

Nothing else is.

Princes do but play us; compared to this,

All honor's mimic, all wealth alchemy

Having such a state he, his beloved and his chamber incorporate the whole world and he can therefore address even the sun:

Thou, sun, art half as happy as we,

In that the world's contracted thus;

Thine age asks ease, and since thy duties be

To warm the world, that's done in warming us.

Shine here to us, and thou art everywhere;

This bed thy center is, these walls thy sphere.

(Donne, 'The Sun Rising')

In this wonderland there is no need of wine even if it be of the divine sort since the lover is ecstatic of the beloved's eyes:

Drink to me only with thine eyes,

And I will pledge with mine;

Or leave a kiss but in the cup,

And I'll not look for wine.

The thirst that from the soul doth rise,

Doth ask a wine divine;

But might I of Jove's nectar sup, 
I would not change for thine

(Ben Jonson, "To Celia")

And this is an ecstasy which mocks the shallow revelry of wine since it is everlasting; it defies time itself:

All other things to their destruction draw,

Only our love hath no decay

This no to-morrow hath, nor yesterday.

Running it never runs from us away,

But truly keeps his, first, last, everlasting day

(Donne, "The Anniversary")

A female reader of these lines - not knowing the historical era whence they spring and the social context underlying that era - would probably covet the addressee's female potency and the irresistible albeit femininely graceful will implicitly revered in these lines. Stepping out of the wonderland of poetry, however, we are jolted into a harsh reality presented by historical record, and discern no sure direction in this maze of seeming confusion where we see the idyllic literary images crossed out by the black ink of the historian.

Here, the female standing close to Venus in literary proximity, finds herself thrown back to and heavily grounded on earth, bound tightly by law and patriarchal convention; a sermon by Thomas Gataker gives the general status as one in which:

the man is as the head, and the woman as the body.....

and as it is against the order of Nature that the

body should rule the head :so it is no less against the

course of all good order that the woman should usurp

authority to herself over her husband, her head

(qtd. Hobby 1993, 32). 
A more detailed picture of the relation between the "head" and the "body" is given in the 1563 Homilies sermon "Of the State of Matrimony": "if thou lovest him only because he is gentle and courteous, what reward will God give thee therefore?" (Cowen Orlin 2006, 162 ). A wife should, even if her husband be "not gentle" suffer the superior severity of the male family "head" with patience and humility. Married life was a duty to be carried out uncomplainingly as if matrimony were punitive for the daughters of Eve and mutual incompatibility inevitable. Obviously, what many Renaissance would-be brides heard as practical advice offered no illusions as to lasting love, prevailing pleasure, or natural unfolding of marital harmony. These ideals however, were not wholly dismissed, but rather, had their own historically tempered logic. This view of female inferiority was not an invention of the Renaissance; that "All pursuits of men are the pursuits of women also, but in all of them a woman is inferior to a man" (Dictionary of quotations 1968,$443 ; 8$ ) goes as far back as Plato. From the pagan world of the great philosopher continues a tradition which is echoed in the Christian era of the great bard John Milton:

Therefore Gods universal law

Gave to the man despotic power

Over his female in due awe

(Milton, "Samson Agonistes")

And since this is to be the destiny ordained by Divine Will on the eternal fate of Adam's progeny it follows that:

He for God only, she for God in him

(Milton, Paradise lost; 4; 299)

Therefore, one image juxtaposed by history with the image of the irresistible ladylove is that of the subservient "body", only moving in accordance with the whims of its "head". Even in Donne's "Valediction forbidding mourning" the celebrated merger is not, as Hobby wittily observes, "a union of equals: the lady's part in the relationship is to be the "fixed foot" of the compasses, only moving when the roaming foot rotates" (Hobby 1993, 33, emphasis not in the original).

The age simply cannot offer equality in its modern sense, even to its most liberalminded individuals. Such notions of female inferiority could, some two centuries later, be light-heartedly mocked by George Eliot in Adam Bede with the assertion, "I am not denyin' that women are foolish: God Almighty made "em to match the men." (Dictionary of Quotations 1980, 200) but they were at the time rooted strongly in common belief.

The image of the adored Lady is artistically alien with the "body" metaphor but her being portrayed in a metaphorical image of "treasure" is truly poetic. In the Renaissance however, the lady was also literally a treasure, a financial asset, a possession. The age was one in which according to the Encyclopedia of the Renaissance a man was defined not by his identity but by what he possessed: 
The Renaissance was an age that experienced unprecedented changes in the acquisition of material objects, as consumption habits and cultural values led individuals to an entirely new relationship with their possessions..... while people increasingly began to seek out new possessions, these possessions began to define them in turn, shaping.... their identities.

(1999 vol. 4, 62-3)

The fair sex was one among other possessions. What was a daughter's claim to her father's inheritance was brought on marriage to the conjugal hut or mansion as the case may have been. This wealth went, in effect, from the hands of the father to those of the husband with the female acting as the empty space of the transaction. In the case of property-owning widows the property would automatically have been transferred to the next husband. Maybe rather bitter to the pretensions of modern taste, marriage was within such a framework of male-dominated economic relations, a deal - albeit an auspicious one in the eyes of the age.

This deal could however, despite its economic roots, bear mutuality, since "mutuality was the ideal recommended by the preachers, humanists and other moral instructors" (vol. 6:320). The fact that marriage was an economic rather than emotional choice and a wide age gap - in most cases - separated the two spouses must have seemed irrelevant to the honorable orators and to the age in general. It would probably not be too unreasonable to surmise that with the radiance emanating from economic welfare for the majority of people - in that, as in any other age - the costlier the dowry, the finer the mutuality derived from the husband's satisfaction with his newly gained capital on the one hand and the wife's self-confidence in her overall worthiness on the other.

From there it follows that with a substantially high dowry, a praise elevating the lady in "possession" of it to the status of goddess would not be unjustified. Even where there may have been distaste for such praise on the female side as voiced by Isabella in Middleton's Women Beware Women:

Oh, the heartbreakings

Of miserable maids, where love's enforc'd!

The best condition is but bad enough:

When women have their choices, commonly

They do but buy their thraldoms, and bring great portions

To men to keep 'em in subjection

... No misery surmounts a woman's 
Men buy their slaves, but women buy their masters

(qtd. Hobby 1993, 35)

this certainly would not have been the case on the male side, especially if the bondage were even if only in the wishing of male fancy - between a female of a wealthy family and a man of humble origin. The praise is basically sound in its being wholly consistent with the ambiance of a male-dominated, possession-seeking era. Love and possession are so closely linked that sometimes the language of the two overlaps:

Come live with me, and be my love,

And we will some new pleasures prove

Of golden sands and crystal brooks

With silken lines and silver hooks.

(Donne, "The Bait")

A fine arrangement of gold, silver and crystal, with loving, fishing and living.

It is this language of economy that may explain the seeming confusion encountered on the borderline of literature and history, in that the poet makes a deal in an age which is basically an age of aspiration for trade: if the lady is willing to accept him as her "head" and be his obedient "body", he is willing to adore her in his everlasting verse; when this is compounded with her bringing him material wealth and possessions with her dowry, the culmination of his adoration occurs.

"The idolizing courtship of the desired mistress, then, is inviting her at best to a legal relationship where she has no independent existence but becomes a man's possession; this is encoded in the language adopted by the male poets." (Hobby 1993, 36). In addition to the image of woman as "treasure" we have yet another image of the woman in the Renaissance period: the image of the "free female". Some poetry of the age invites the would-be mistress to sexual relationships. Here again the literary scene harshly clashes with social history; women were not free to have relationships as they pleased. Not only was the force of ideological restraint behind the demand for virginity until marriage or as the case may have been, procession of the hearse, but also that of social and economic considerations.

The head of the patriarchal system, the father, wanted assurance that his inheritance would be enjoyed by his rightful heir, the seal of whose legitimacy would have been in his wife's maidenhead. Virginity was, therefore, the female's capital which secured both her honor and economic security in her husband's house.

This social reality however would not have guaranteed that all men observe its limits ; in a society where the female is the possession of the male there would be the desire for unlimited possession. Such a desire would also have been given impetus by another belief of the era, a belief which, in addition to fueling passion in some, would naturally have evoked anxiety in others. In an article on female readership of romances, Helen Hackett discusses the fundamental anxieties concerning the humanist educational program; the unlearned were 
given literacy in order to read godly books but literacy, knowing no boundaries, could also unlock the doors of books with immoral content.

She states that one of the premises on which such concerns were based was that "romances exercise undue freedom concerning erotic matters" this being of significant import since "women are susceptible to the charms of such erotic entertainment." (10).

Given the massive libidinous capacity the Renaissance attributes to the female figure on the one hand and her status as male possession on the other, the fancy of the Renaissance poet was bound to flare and present the female with "erotic entertainments" imbued with optimistic anticipation of her positive response. The focus of such fantasies is where Carew wished to behold:

$$
\begin{aligned}
& \text { Thy bared snow, and thy unbraided gold } \\
& \text { There, my enfranchised hand, on every side } \\
& \text { Shall o're thy naked polish'd Ivory slide “ }
\end{aligned}
$$

(qtd. Hobby 1993, 39)

The reference to gold and ivory unconsciously inculcates to the would-be mistress her status as a commodity at the disposal of his "enfranchised" hand. Such a view of the unsatisfiable woman would, no doubt, have also evoked anxieties which can partly be discerned from Joseph Swetnam's warning that:

"women have a thousand ways to entice thee and ten thousand ways to deceive

thee and all such fools as are suitors unto them: some they keep in hand with

promises and some they feed with flattery, some they delay with dalliances...”

(qtd. Hobby 1993, 40)

Those who are "such fools" may be the very ones who desire an unlimited relationship with the ladies; "fools" since they do not realize the lady's apparent coyness is, as implied in the text, a self-conscious procrastination aimed at making utmost use of male vanity for her immediate pleasure of tantalization or future prospect.

In any case here it is the lady who apparently, by keeping some in hand with promises and feeding others with flattery and delaying yet others with dalliances is bidding her time for the best possible deal; what can be seen here is that the language is, it seems, definitely the male language of trade. The overall essence of the age in terms of gender relations is succinctly captured by Hackett: 
"Women were symbols of the property and power held and exchanged by men, whether as daughters deployed in marriage alliances, or as wives and mothers whose chastity ensured the perpetuation of the name and state of the male head of the family."

(Hackett 2000, 16)

Obviously this view has its own reasoning and supporting voices, whether it be in the language of the commons or the refined rhetoric of the orator.

The boldest expression however, is in the leaves of literature. In that era as in all eras, it is the voice of literature which is the most mysterious and the most pleasing.

\section{CONCLUSION}

Overall, it seems the confusion between historical perspective and literary rhetoric as regards the status of woman in the Renaissance era is only apparent to the modern perception; with the logic of the era's mindset, contradiction can be dismissed as irrelevant.

The history of the age speaks the language of economic expansion, trade, and power relations embedded in the fixities of a firm patriarchal dominance; so too does literary diction. This diction engages the ladylove in variations of a mutually beneficial arrangement. In one orientation of this arrangement woman is the subservient "body" for man as ruling "head." If she the ladylove as body, bows down to the poet as her head, then he in exchange is willing to subdue his verse to the adoration of her beauty and sacrifice his words to the praise of her virtues.

In a second nuance of the same mutually beneficent man-woman economy, where the ladylove and all she owns can belong to the poet, he in return is willing to make her the jewel of his poetry. And in yet another orientation of the arrangement, the male poet, supposing the extent of the ladylove's libidinal passion and her willingness to be possessed, is willing to flatter her with the grace of his poetic invitation to love in return for her feminine charms. In each case there is no confusion, there is the unambiguous language of trade and the literary stamp of its execution.

\section{References}

[1] Hobby Elaine, "The politics of gender." Cambridge companion to English literature Donne to Marvell. _Cambridge University Press, 1993, 31-51.

[2] M. H. Abrams, Ed., Norton Anthology of English literature. The major authors. W. W Norton and company, 1987.

[3] Cowen Orlin Lena, "Life and domesticity", Concise companion to English Renaissance Literature._Ed. Lorna B. Hamilton. Blackwell Publishing, 2006.

[4] Encyclopedia of the Renaissance. Board of editors. Charles Scribner's Sons. 1999. New York. 10019, 4 (1999) 62-63, 6 (1999) 320. 
[5] Hackett Helen., Women and romance fiction in the Renaissance. Cambride University Press, 2000.

[6] Dictionary of Quotations Delacorte Press, New York, 1968, 443; 8, 17.

[7] Oxford Dictionary of Quotations Book Club Associates, 1980. 